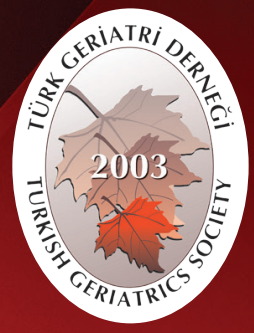

Turkish Journal of Geriatrics

DOI: 10.31086/tigeri.2018240412

2018:21 (2):109-117

- Sinan YENAL ${ }^{1}$

- Gökhan KESER ${ }^{2}$

- Aliye MANDIRACIOĞLU³

- Mehmet Akif YALÇIN ${ }^{2}$

- Başak BAYRAM ${ }^{4}$

- Fehmi AKÇiÇEK²

CORRESPONDANCE

Sinan YENAL

Dokuz Eylül University, Health Care Services

Vocational School, İzmir, Türkiye

Phone: 02324124734

Fax: 02322770739

e-mail: sinan.yenal@deu.edu.tr

Received: 03/01/2018

Accepted: 17/04/2018

Dokuz Eylül University, Health Care Services

Vocational School, İzmir, Turkey

Ege University, Faculty of Medicine,

Department of Internal Medicine, İzmir, Turkey

Ege University, Faculty of Medicine,

Department of Public Health, Izmir, Turkey

${ }^{4}$ Dokuz Eylül University, Faculty of Medicine,

Department of Emergency, İmir, Turkey

Presented in the $4^{\text {th }}$ International Paramedics Congress and Ambulance Rally, December 2016, Muğla, Turkey.

\section{THE DETERMINATION OF THE STATUS OF EMERGENCY DEPARTMENT USE BY ELDERLY PATIENTS AND OF THE INDICATORS FOR AMBULANCE USE}

\section{Abstract}

Introduction: This study was prepared with the objective of determining the ratio of use of ambulances by the patients 65 years of age and older who applied to emergency department and the indicators for the use of ambulances.

Materials and Method: This cross-sectional research study, enrolled patients at least 65 years of age or older, who applied to the emergency department in Izmir Dokuz Eylül University Hospital. Two measurement tools were prepared with the objective of gathering the study data. The first measuring tool was prepared with the objective of evaluating the indicators of ambulance use by the patients, whereas the second measuring tool was for the situations of using emergency department.

Results: 555 patients were included in the study. Only $34.2 \%$ of these patients reported that they came to the emergency department with an ambulance. It was observed that patients living with their families, and those with medical emergencies, i.e. who did not experience a trauma or an accident, used ambulances less frequently for going to the emergency department $(p<0.05)$. Among patients who came to the emergency department with private vehicles, $59.2 \%$ stated that they did not call an ambulance because they thought that it would be quicker to come with their own resources. On the other hand, among patients who came to the hospital with an ambulance, a ratio of $67.4 \%$ replied that they called the ambulance because of emergency.

Conclusion: The results of this study suggest that public awareness about 112 ambulance systems should be increased, especially for elderly patients.

Keywords: Geriatrics; Ambulance; Emergency Medical Services; Emergency Service, Hospital

ARAŞTIRMA

\section{YAŞLI HASTALARIN ACIL SERVIS KULLANIM DURUMU VE AMBULANS KULLANIM BELIRLEYICILERININ SAPTANMASI}

\section{$\ddot{O}_{z}$}

Giriş: Bu çalışma acil servise başvuran 65 yaş ve üzeri hastaların ambulans kullanım oranını ve ambulans kullanım belirleyicilerini saptamak amacıyla hazırlanmıştır.

Gereç Yöntem: Kesitsel tipte planlanan bu araştırmanın evrenini, İzmir Dokuz Eylül Üniversitesi Hastanesi'nin acil servis birimine başvuran 65 yaş ve üstü hastalar oluşturmuştur. Çalışmanın verilerini toplamak amacı ile iki adet ölçme aracı hazırlanmıştır. Birinci ölçme aracı hastaların ambulans kullanım belirleyicilerini, ikinci ölçme aracı ise AS kullanım durumlarını değerlendirmek amacıyla hazırlanmıştır.

Bulgular: Araştırmaya 555 hasta alınmıştır. Çalışmaya alınan hastaların \%34.2'sinin acil servise ambulans ile geldiği bulunmuştur. Ambulans ile gelen hastalar ise, \%67.4 oranında acil durum nedeni ile ambulansı aradıkları yanıtını vermiş̧ir. Ailesi ile birlikte yaşayan ve nontravmatik hastaların, acil servise ulaşmak için daha az sıklıkta ambulans kullandığı görülmüştür $(p<0.05)$. AS birimine özel araç ile gelen hastaların \%59.2'lik kısmı, kendi olanaklarıyla gelmenin daha çabuk olacağını düşündükleri için ambulans aramadıklarını belirtmiştir.

Sonuç: Bu çalışma özellikle yaşlı hastalarda 112 Ambulans sistemi hakkında halkın bilinçlendirilmesi gerektiğini ortaya koymaktadır.

Anahtar sözcükler: Geriatri; Ambulans; Acil Tıp Hizmetleri; Acil Hizmet, Hastane 


\section{INTRODUCTION}

Just as elderly patients present to health centres, they present more frequently to emergency departments (EDs) for acute and complex problems. They feel the need to receive more intensive service and to be subjected to more diagnostic procedures. Consequently, they remain in EDs for a longer time. Prior studies have observed that the ratio of patients aged 65 years and older presenting to EDs in Turkey varied between 9\% and 18\% (1-6). Studies in different countries have reported that this ratio varied between $15 \%$ and $47 \%$ (7-10).

Patients presenting to EDs have been evaluated in various studies conducted in Turkey and worldwide, and these evaluations were generally based on information obtained from hospital records. Although the number of patients arriving at hospitals via an ambulance has been quantified, the number of studies that examined the reasons for in detail this is limited (11-13). It is important to determine the reasons patients presenting to EDs call or do not call an ambulance so that the use of 112 emergency medical services (EMS) can be optimised.

In this study, we aimed to determine the ratio of the use of ambulances by patients aged 65 years and older who presented to the ED of Dokuz Eylül School of Medicine and evaluated the indicators of ambulance use.

\section{MATERIALS AND METHOD}

This cross-sectional research study comprised patients aged 65 years and older who presented to the ED of Izmir Dokuz Eylül University Hospital between 1 August 2015 and 31 August 2015. Sampling was not done, and the study targeted the entire population. Patients whose general condition was such that were not suitable to attend interviews, who were sent to EDs at other polyclinics and who died in EDs were excluded. The first arrivals of patients who presented to the
ED more than once within the study period were included. Of 9484 patients who presented to the ED of Dokuz Eylül University Hospital during the study period, 820 (8.6\%) were 65 years and older. After excluding patients with repeat arrivals, 755 met the inclusion criteria. Of these, 84 (11.2\%) refused to participate, 64 (8.4\%) could not be contacted, 27 (3.5\%) were in a poor general condition because of which information could not be obtained, 11 (1.5\%) were excluded as they were directed from the ED to another polyclinic within the hospital and 14 (1.9\%) died. Finally, 555 (73.6\%) could be contacted and were included in this study.

By scanning the literature and obtaining the views of experts, two measurement tools were prepared that were suitable to the objective of the study. The first measurement tool determined the patients' individual attributes, economic status, social security information, educational status, reasons and conditions for presenting to the ED and reasons for calling an ambulance. The tool was filled through face-to-face interviews held with the patient or their relatives. The second measurement tool determined the outcome of elderly patients in the ED. In this tool, the reason (traumatic or nontraumatic) for patients presenting to the ED, status of care at the ED (outpatient or inpatient), time that patients remained in the ED, status of requesting a consultation and the unit (surgical or internal medicine unit) in which inpatients were admitted were obtained by entering the related information into the hospital computer system.

The elderyl patients in this study are divited in two groups. First is the ambulance group (112 EMS Ambulance, Private ambulance and Institution ambulance), the second it's the private vehicle group (own cars, taxies, public busses etc.).

Data were evaluated using SPSS for Windows 15.0 software. The "Chi-square (chi-sq)" test was used to compare the situations of patients presenting to the ED with their sociodemographic status and to compare variables that could influence 
their presentation to the ED with their status of ambulance use. The independent samples t-test was used to compare the ages of patients presenting to the ED, distance travelled to present to the ED, onset of complaints that made presentation to the ED necessary and duration of ED stay with their status at presentation. Logistic regression analysis was used for variables that were significant at the end of single-variable analysis.

This study was approved by the Dokuz Eylül University, Noninterventional Research Ethics Committee dated 21 August 2015, protocol Number 2197-GOA and decision number 2015/19-43.

\section{RESULTS}

Of 190 patients (34.2\%) who presented to the ED via an ambulance, most ( $n=177 ; 93.2 \%)$ presented via the 112 EMS (Table 1).

A comparison of the sociodemographic findings of patients presenting to the ED via an ambulance is shown in Table 2. Most elderly patients who preferred to present to the ED via a private vehicle were married $(P=0.02)$ or lived with their families $(P=0.01$; Table 2).

Reasons for calling or not calling an ambulance by patients who presented to the ED via a private vehicle or an ambulance is shown in Table 3 .
When the complaints of patients were considered, 468 (84.3\%) presented to the ED due to nontraumatic complaints. The ratio of patients presenting to the ED via an ambulance was statistically significantly lower among those without traumatic complaints than among those with traumatic complaints ( $p=0.02$; Table 4).

The comparison according to age, distance travelled for presenting to the ED, onset of complaints requiring presentation to the ED and duration of stay in the ED of patients coming via an ambulance or a private vehicle is shown in Table 5. Accordingly, patients who presented to the ED via an ambulance were statistically significantly older and remained in the ED for a significantly longer period than those who presented to the ED via a private vehicle $(p<0.01$ and $p<0.01$, respectively; Table 5).

Logistic regression analysis of the variables found to be significant after single-variable analysis is shown in Table 6. Accordingly, the rate of presenting to the ED via an ambulance was 13.07 (2.92-58.58)-fold higher for those living in a rest home and was 9.34 (6.20-14.06)-fold higher for those who called the 112 EMS within the past year. In contrast, the status of being married decreased the use of ambulances by 0.60 (0.40-0.93)-fold, and living together with family decreased it 0.57 (0.38-0.87)-fold.

Table 1. Status of patients presenting to the emergency department.

\begin{tabular}{lrr}
\hline Status of presenting to the ED $(\mathbf{n = 5 5 5 )}$ & $\mathbf{n}$ & Total \\
\hline Via a private vehicle & 365 & 65.8 \\
Via an ambulance & 190 & 34.2 \\
Via an ambulance $(n=190)$ & & \\
112 EMS ambulance & 177 & 93.2 \\
Private ambulance & 6 & 3.1 \\
Institution ambulance & 7 & 3.7 \\
\hline
\end{tabular}

* Column percentage 
Table 2. Sociodemographic attributes of the patients and statuses of presenting to the emergency department.

\begin{tabular}{|c|c|c|c|c|c|c|c|c|}
\hline \multirow{2}{*}{ Variable } & \multicolumn{2}{|c|}{ Ambulance } & \multicolumn{2}{|c|}{ Private vehicle } & \multicolumn{3}{|c|}{ Total } & \multirow[b]{2}{*}{$p$} \\
\hline & $\mathbf{n}$ & $\% \star$ & & \%* & n & $\%$ \%* & $\chi^{2}$ & \\
\hline \multicolumn{9}{|l|}{ Gender $(n=555)$} \\
\hline Female & 94 & 36.0 & 167 & 64.0 & 261 & 47.1 & 0.69 & 0.40 \\
\hline Male & 96 & 32.7 & 198 & 67.3 & 294 & 52.9 & & \\
\hline \multicolumn{9}{|l|}{ Marital status $(n=549)$} \\
\hline Married & 142 & 32.1 & 300 & 67.9 & 442 & 80.5 & 5.31 & 0.02 \\
\hline Single & 47 & 43.9 & 60 & 56.1 & 107 & 19.5 & & \\
\hline \multicolumn{9}{|l|}{$\begin{array}{l}\text { Status of living } \\
(n=542)\end{array}$} \\
\hline With family & 135 & 31.8 & 289 & 68.2 & 424 & 78.2 & 6.97 & $0.01 \downarrow$ \\
\hline With children & 30 & 38.5 & 48 & 61.5 & 78 & 14.2 & 0.57 & 0.45 \\
\hline Rest home & 13 & 86.7 & 2 & 13.3 & 15 & 3.0 & 18.40 & $0.01 \downarrow$ \\
\hline Alone & 9 & 39.1 & 14 & 60.9 & 23 & 4.2 & 0.21 & 0.65 \\
\hline Caregiver & 1 & 50.0 & 1 & 50.0 & 2 & 0.4 & 0.21 & $0.57^{\star \star *}$ \\
\hline \multicolumn{9}{|l|}{$\begin{array}{l}\text { Monthly income } \\
(n=512)\end{array}$} \\
\hline 1000 TL or less & 42 & 32.1 & 89 & 67.9 & 131 & 25.6 & 0.01 & 0.94 \\
\hline 1001-2000 TL & 104 & 34.8 & 195 & 65.2 & 299 & 58.4 & & \\
\hline 2001-3000 TL & 22 & 32.8 & 45 & 67.2 & 67 & 13.1 & & \\
\hline 3001 or more & 4 & 26.6 & 11 & 73.4 & 15 & 2.9 & & \\
\hline \multicolumn{9}{|l|}{ Social security $(n=555)$} \\
\hline Emekli Sandığı $ı^{a}$ & 71 & 34.8 & 133 & 65.2 & 204 & 36.8 & 0.05 & 0.83 \\
\hline $\mathrm{SSK}^{\mathrm{b}}$ & 72 & 35.1 & 133 & 64.9 & 205 & 36.9 & 0.11 & 0.74 \\
\hline BAĞ-KURc & 30 & 30.6 & 68 & 69.4 & 98 & 17.7 & 0.69 & 0.40 \\
\hline Private Insurance & 1 & 14.2 & 6 & 85.8 & 7 & 1.3 & 1.25 & $0.24^{\star \star \star}$ \\
\hline None & 14 & 38.9 & 22 & 61.1 & 36 & 6.5 & 0.37 & 0.54 \\
\hline Other & 2 & 40.0 & 3 & 60.0 & 5 & 0.9 & 0.07 & $0.55^{\star \star \star}$ \\
\hline \multicolumn{9}{|l|}{$\begin{array}{l}\text { Educational status } \\
(n=548)\end{array}$} \\
\hline Illiterate & 23 & 29.5 & 55 & 70.5 & 78 & 14.2 & 0.78 & 0.37 \\
\hline $\begin{array}{l}\text { Primary school } \\
\text { graduate }\end{array}$ & 79 & 39.5 & 121 & 60.5 & 200 & 36.5 & & \\
\hline $\begin{array}{l}\text { Middle school } \\
\text { graduate }\end{array}$ & 42 & 33.1 & 85 & 66.9 & 127 & 23.2 & & \\
\hline $\begin{array}{l}\text { High school } \\
\text { graduate }\end{array}$ & 29 & 35.8 & 52 & 64.2 & 81 & 14.8 & & \\
\hline University graduate & 16 & 25.8 & 46 & 74.2 & 62 & 11.3 & & \\
\hline \multicolumn{9}{|l|}{$\begin{array}{l}\text { Status of health of family } \\
(n=461)\end{array}$} \\
\hline Yes & 11 & 33.3 & 22 & 66.7 & 33 & 7.2 & 0.01 & 0.92 \\
\hline No & 139 & 32.5 & 289 & 67.5 & 428 & 92.8 & & \\
\hline \multicolumn{9}{|c|}{$\begin{array}{l}\text { Status of calling } 112 \text { within the } \\
\text { past year } \\
(n=552)\end{array}$} \\
\hline Yes & 120 & 67.6 & 57 & 32.4 & 177 & 32.1 & 130 & $0.01 \downarrow$ \\
\hline No & 69 & 18.4 & 306 & 81.6 & 375 & 67.9 & & \\
\hline
\end{tabular}

*Line percentage $\quad * *$ Column percentage ***Fisher's Exact Test was applied.

aPension Fund bocial Security Institution $\quad$ 'Pension Fund for Artisans and Self-employed 
Table 3. Reasons for calling or not calling an ambulance by patients who presented to the emergency department via a private vehicle or an ambulance.

\begin{tabular}{|c|c|c|}
\hline \multirow{2}{*}{ Reason } & \multicolumn{2}{|c|}{ Total } \\
\hline & $\mathbf{n}$ & \%* \\
\hline \multicolumn{3}{|l|}{ Patients who presented to the ED via a private vehicle $(n=363)$} \\
\hline 1- Thought it would be quicker to come with their own resources & 215 & 59.2 \\
\hline \multicolumn{3}{|l|}{ 2- Thought that it was not an emergency that warranted calling an ambulance } \\
\hline 3- Did not think to call an ambulance & 113 & 31.1 \\
\hline $\begin{array}{l}\text { 4- The fact that the ambulance may not go to the hospital he/she wanted } \\
\text { 5- To not pay a fee }\end{array}$ & 13 & 3.6 \\
\hline 6- Because the hospital was close & 5 & 1.4 \\
\hline \multirow{2}{*}{ 7- Other } & 4 & 1.1 \\
\hline & 3 & 0.8 \\
\hline $\begin{array}{l}\text { Patients who presented to the ED via an ambulance } \quad(n=181) \\
\text { 1- Due to an emergency situation } \\
\text { 2- To transport the patient }\end{array}$ & 10 & 2.8 \\
\hline 3- Thought that they would come to the hospital quicker & 122 & 67.4 \\
\hline 4- Since it was an institutional ambulance & 25 & 13.8 \\
\hline 5- Since oxygen support was needed & 13 & 7.2 \\
\hline \multirow[t]{3}{*}{ 6- Other } & 7 & 3.9 \\
\hline & 4 & 2.2 \\
\hline & 10 & 5.5 \\
\hline
\end{tabular}

* Column percentage

Table 4. Variables that could influence patients presenting to the emergency department with the relationship of ambulance use.

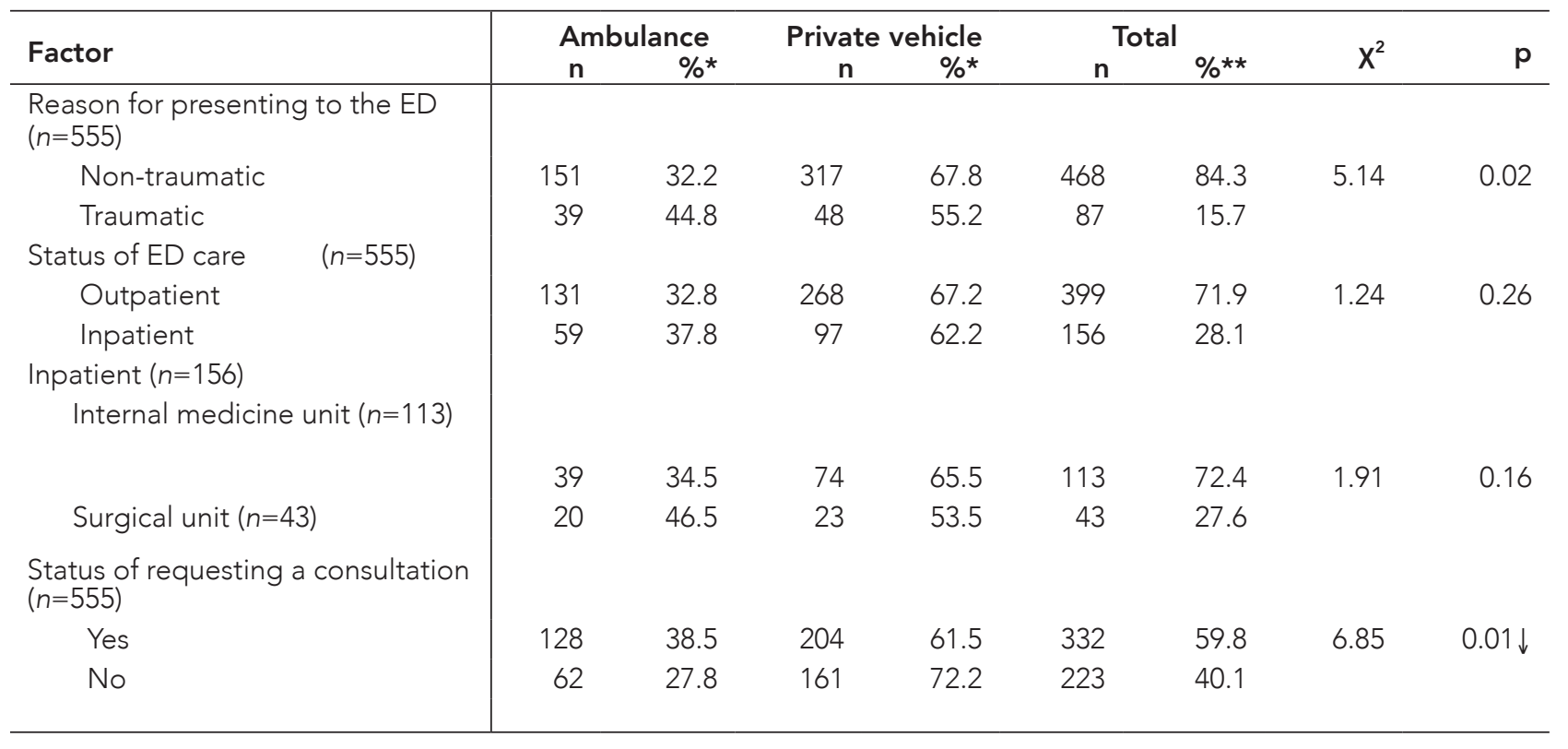

\footnotetext{
*Line percentage $\quad * *$ Column percentage
} 
Table 5. Comparison according to some characteristics of the patients.

\begin{tabular}{|c|c|c|c|c|}
\hline Characteristics & 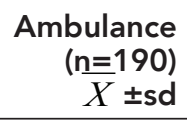 & $\begin{array}{r}\text { Private vehicle } \\
\qquad \begin{array}{r}(n=365) \\
X \pm s d\end{array}\end{array}$ & $\mathbf{t}$ & $p$ \\
\hline Age (years) & $78.2 \pm 7.9$ & $76.0 \pm 7.3$ & -3.24 & $0.01 \downarrow *$ \\
\hline $\begin{array}{l}\text { Distance travelled for presenting } \\
\text { to the ED }(\mathrm{km})\end{array}$ & $20.8 \pm 25.7$ & $19.1 \pm 18.2$ & 0.79 & 0.43 \\
\hline $\begin{array}{l}\text { Time from when the complaints } \\
\text { started and to presenting to the ED } \\
\text { (min) }\end{array}$ & $21.8 \pm 38.4$ & $26.5 \pm 36.0$ & -1.38 & 0.16 \\
\hline Duration of stay in the ED (min) & $752.2 \pm 872.9$ & $581.0 \pm 780.7$ & -3.44 & $0.01 \downarrow^{*}$ \\
\hline
\end{tabular}

*The $z$ value has been given.

Table 6. Significant variables that influence presentation to the emergency department via an ambulance and the logistic regression model.

\begin{tabular}{|c|c|c|c|c|}
\hline Variable & Beta & $p$ & $\mathrm{OR}^{\mathrm{a}}$ & $95 \% \mathrm{Cl}^{\mathrm{b}}$ \\
\hline Age (continuous) & 0.038 & $0.01 \downarrow$ & 1.04 & $1.02-1.06$ \\
\hline Marital status (married) & -0.504 & 0.02 & 0.60 & $0.40-0.93$ \\
\hline Living together with family & -0.557 & $0.01 \downarrow$ & 0.57 & $0.38-0.87$ \\
\hline Living in a rest home & 2.571 & $0.01 \downarrow$ & 13.07 & $2.92-58.58$ \\
\hline Calling the 112 service within the past year & 2.234 & $0.01 \downarrow$ & 9.34 & $6.20-14.06$ \\
\hline Reason for presenting to the ED (trauma) & 0.478 & 0.02 & 1.61 & $1.01-2.57$ \\
\hline Request for consultation & 0.488 & $0.01 \downarrow$ & 1.63 & $1.13-2.35$ \\
\hline
\end{tabular}

adds ratio ${ }^{\mathrm{b}}$ Confidence interval

\section{DISCUSSION}

To the best of our knowledge, our study is the first in Turkey to examine the reasons for patients 65 years and older presenting to the ED via an ambulance. The most basic reason for using ambulances was the thought that the patient was in an emergency situation. However, patients who presenting to the ED via private vehicles stated that they did not call an ambulance because they thought that it would be quicker to come via their own resources.
Among our study patients, $34.2 \%$ presented to the ED via ambulance. In various studies conducted in Turkey, the ratio of patients 65 years and older presenting to the ED via an ambulance varies between $5.6 \%$ and $40.0 \%(2,5,6,14,15)$.

Individuals who were married came to the hospital ED less frequently with an ambulance $(\mathrm{OR}=0.60)$. In the study made in Australia by Clark et al. in 1999, they found that in persons 65 years of age and older, being married decreased to a significant extent the use of an ambulance ( $P R=0.69)$ (11). In the 
study made in Australia by Kerr et al. in which they evaluated the situations of coming to the hospital with an ambulance of all age group patients who had had a heart attack, it was found that $59 \%$ of the married patients came to the hospital with an ambulance (16). This difference can be explained with societal understanding. It was thought that the presence in Turkey of persons who would assist the patient would sometimes be the reason for paying insufficient attention to the other aid choices. It was found to be statistically significant that individuals who lived in a rest home came to the ED more frequently with an ambulance. It was thought that the result was also influenced by using institutional ambulances for persons living in a rest home.

It was observed that within the past year, the request for an ambulance in the situation of requesting aid from the 112 EMS had increased to a significant extent (OR=9.34). These known behaviors can be explained as a repetition. It was observed that persons who had requested help from the Ambulance services would also increase the probability of requesting an ambulance later in their lives.

Most patients who presented to the ED via private vehicles thought that 'it would be quicker to come with their own resources'. If they can provide for this with their own resources, they present to the ED as soon as possible without requesting aid.

The most important reason for preferring to present patients to the hospital ED via an ambulance is the thought that the patient is in an emergency. This situation can be interpreted in two ways. First, they could request ambulance assistance as they really think that their situation is an emergency. Second, they believe that the hospital would take more interest in patients who present to the ED via an ambulance or that they would not experience problems when being admitted to the hospital.

When the complaints of patients were evaluated, 84.3\% presented to the ED due to nontraumatic complaints. The ratio of nontraumatic patients presenting to the ED via an ambulance was statistically significantly lower and the frequency of ambulance use by patients with trauma was high (OR=1.61). In 1999, Clark et al. found that the use of ambulances for trauma in people 65 years and older significantly increased (11).

Of the patients who came to the ED, consultations were requested from various units for $59.8 \%$ of the patients during treatment. It was found that more consultations were requested for patients who came to the hospital with an ambulance (OR=1.63). In the study made by Loğoğlu et al., consultations were requested for $43.4 \%$ of the elderly patients who came to the ED. It was observed that has the age increased, there was also an increase in the ratios of requesting consultations (17). In the study made by Sinoff et al., it was found that of all the consultations requested in the ED, $49.3 \%$ were requested for patients in the geriatric age group (18). The results found in this study were generally found to be in conformity with the other studies.

When the times remaining in the ED of patients who came to the ED were examined, it was observed that the patients who came with an ambulance remained for a longer time to a significant extent in the ED. In the study made by Loğoğlu et al., the time of remaining in the ED was found to be 2.9 hours (17). In the study made by Young et al., the time of elderly patients remaining in the ED was found to be 3.5 hours (9). In the study made by Kennelly et al., the time of elderly patients remaining in the ED was found to be 9.2 hours (12). In the study made by Ross et al., the time of elderly patients remaining in the ED was found to be 6.53 hours (19). In this study, the average time of elderly patients remaining in the ED was found to be 10.8 hours. In general, the time of remaining in the ED was in harmony with the other studies. The patients who came with an ambulance remained in the EU for a longer time in a statistically significant manner compared to the patients who came with a private vehicle. The reason for this could be that the health conditions of the patients who came with an ambulance could 
be more severe compared to the others. More help is requested from the 112 EMS for patients who are more severe and in worse condition.

The fact that our study included a fixed period (only one month) and that it coincided with the summer season could be a limitation from the aspects of period and time. The study was conducted using data from patients presenting to only the ED of the Dokuz Eylül University Hospital. Consequently, generalisations related to the results are unsuitable. Furthermore, as the study was crosssectional, the results were limited in the explanation of the relationships.

According to the conclusions of this study,

\section{REFERENCES}

1. Satar S, Sebe A, Avcı A, Karakuş A, İçme F. Emergency department and elderly patient. Çukurova University, Journal of Medicine School 2004;29:43-50. (in Turkish).

2. Akpınar O, Türkdoğan KA, Kapçı M, Duman A. Use of emergency department by elderly patients. J Clin Anal Med 2014;6(152):310-4. (in Turkish).

3. Mert E. Use of emergency departments by elderly patients. Turk J Geriatrics 2006;9(2):70-4. (in Turkish).

4. Ünsal A, Çevik AA, Metintaş S, Arslantaş D, İnan OÇ. Emergency department visits by elder patients. Turk J Geriatrics 2003;6(3):83-8. (in Turkish).

5. Şahin S, Boydak B, Savaş S, Yalçın MA, Akçiçek F. Characteristics of patients aged 65 and over in the emergency department. Akad Geriatri 2011;3(1):416. (in Turkish).

6. Zenginol M, Al B, Genç S, et al. Characteristics of patients aged 65 and over in the emergency department. J Emerg Med 2011;10:27-32. (in Turkish).

7. Schumacher JG, Deimling GT, Meldon S, Woolard B. Older adults in the emergency department: predicting physicians' burden levels. J Emerg Med 2006;30(4):455-60. (PMID:16740465). the main reason for calling an ambulance by the patients who came to the ED with an ambulance was the thought that "there was an urgent situation". The main reason for not calling an ambulance by the patients who did not come with an ambulance was the thought that "it would be quicker to come with their own resources". It was found that married patients and those with medical emergencies, i.e. without history of accidents and traumas used ambulances less frequently for coming to the ED. The results of this study suggest that public awareness about 112 EMS should be increased, especially for elderly patients.

8. Rutschmann OT, Chevalley T, Zumwald C, Luthy C, Vermeulen B, Sarasin FP. Pitfalls in the emergency department triage of frail elderly patients without specific complaints. Swiss Med Wkly 2005;135(910):145-50. (PMID:15832233).

9. Young JO. Ambulance and Public Hospital Emergency Department Utilisation by Elderly People in Perth Western Australia [e-book]. The University of Western Australia; 2009 pp 110 [Internet] Available from: NetLibrary Database.http://researchrepository.uwa.edu.au/files/3217105/Young_ Jeanne_Olivia_2009.pdf. Accessed:20.4.2016..

10. Hu SC, Yen D, Yu YC, Kao WF, Wang LM. Elderly use of the ED in an Asian metropolis. Am J Emerg Med 1999;17(1):95-9. (PMID:9928713).

11. Clark MJ, Purdie J, FitzGerald GJ, Bischoff NG, O'Rourke PK. Predictors of demand for emergency prehospital care: an Australian study. Prehosp Disaster Med 1999;14(3):167-73. (PMID:10724741).

12. Kennelly SP, Drumm B, Coughlan T, Collins R, O'Neill D, Romero-Ortuno R. Characteristics and outcomes of older persons attending the emergency 
department: a retrospective cohort study. QJM 2014;107(12):977-87. (PMID:24935811).

13. Dracup K, Moser DK, McKinley S, et al. An international perspective on the time to treatment for acute myocardial infarction. J Nurs Scholarsh 2003;35(4):317-23. (PMID:14735673).

14. Kaldırım Ü, Tuncer SK, Ardıç Ş, et al. Analysis of elderly patients present to the emergency department via ambulance. Turk J Emerg Med 2013;13(4):161-65. (in Turkish).

15. Nur N, Demir ÖF, Çetinkaya S, Tirek N. Evaluation of the 112 emergency service used by older people. Turk J Geriatr 2008;11(1):7-11. (in Turkish).

16. Kerr D, Holden $H$, Smith $J$, et al. Predictors of ambulance use in patients with acute myocardial infarction in Australia. Emerg Med J 2006;23(12):94852. (PMID:17130609).
17. Loğoğlu A, Ayrık C, Köse A, et al. Analysis of non-traumatic elderly patient presentations to the emergency department. Tr J Emerg Med 2013;13(4):171-9. (in Turkish).

18. Sinoff $G$, Clarfield AM, Bergman $H$, Beaudet $M$. A two-year follow-up of geriatric consults in the emergency department. J Am Geriatrics Soc 1998;46(6):716-20. (PMID:9625187)

19. Ross MA, Compton S, Richardson $D$, Jones $R$, Nittis T, Wilson A. The use and effectiveness of an emergency department observation unit for elderly patients. Ann Emerg Med 2003;41(5):668-77. (PMID:12712034). 